\title{
Foliar Spraying of 6-Benzylaminopurine Promotes Growth and Flavonoid Accumulation in Mulberry (Morus alba L.)
}

\author{
Zhen Zhang ${ }^{1} \cdot$ Yu Zhang ${ }^{2} \cdot$ Shanying Zhang ${ }^{1} \cdot$ Lifeng Wang $^{3} \cdot$ Xiaoyu Liang ${ }^{2} \cdot$ Xinquan Wang $^{4} \cdot$ Huiyi Wu $^{5}$. \\ Haotian Zou ${ }^{5}$ Chenghui Zhang ${ }^{1,2}$ (1) Meng Wang ${ }^{2}$
}

Received: 24 January 2021 / Accepted: 6 July 2021 / Published online: 15 July 2021

(C) The Author(s) 2021

\begin{abstract}
Mulberry (Morus alba L.) leaf, a "source of both medicine and food", contains antioxidant ingredients such as flavonoids, alkaloids and polyphenols. The effects of 6-benzylaminopurine (6-BA) treatment on plant growth and flavonoid contents in mulberry leaves were investigated in this study. The expression of rutin (Rut), chlorogenic acid (ChA), isoquercitrin (IQ) and astragaloside IV (Ast) related genes in the flavonoid synthesis pathways was investigated in mulberry leaves. The results showed that 6-BA treatment significantly promoted mulberry differentiation and growth as well as, increased the numbers of new shoots and buds compared to the control. In addition, $30 \mathrm{mg} / \mathrm{L}$ 6-BA significantly increased the contents of Rut, IQ and Ast, and it strongly induced the expression of flavonoid biosynthesis-related genes, including flavonoid 3-O-glucosyltransferase (F3GT), 4-xoumarate-CoA ligase (4CL), phenylalanine (PAL) and chalcone synthase (CHS). The dietary risk assessment of mulberry leaves was based on hormone residues 5 days after treatment with $30 \mathrm{mg} / \mathrm{L}$ 6-BA, and the results showed that the dietary exposure risk of 6-BA was extremely low without causing any health concern. Thus, treatment with $30 \mathrm{mg} / \mathrm{L}$ 6-BA is a new method to improve the medicinal quality and development of high-value mulberry leaf foods without any potential risk.
\end{abstract}

Keywords Mulberry leaf $\cdot$ Flavonoid $\cdot 6$-Benzylaminopurine $\cdot$ Gene expression

\section{Introduction}

Handling Editor: Vaclav Motyka.

Zhen Zhang and Yu Zhang have contributed equally to this article.

Chenghui Zhang

zchlm@hainanu.edu.cn

Meng Wang

wangmeng@hainanu.edu.cn

1 School of Food Science and Engineering, Hainan University, Haikou 570228, China

2 Laboratory of Quality and Safety Risk Assessment for Agro-Products (Haikou), Ministry of Agriculture, Haikou 570102, China

3 Key Laboratory of Biology and Genetic Resources of Rubber Tree, State Key Laboratory Incubation Base for Cultivation \& Physiology of Tropical Crops; Danzhou Investigation \& Experiment Station of Tropical Crops, Ministry of Agriculture and Rural Affairs, Rubber Research Institute, Chinese Academy of Tropical Agricultural Sciences, Haikou, Hainan 571101, People's Republic of China
Mulberry (Morus alba L.) is a popular "affinal drug and diet" plant, and it is widely distributed in the provinces of southern China. Mulberry leaves have been used as feed for

4 Institute of Quality Safety and Nutrition of Agro-Products, Zhejiang Academy of Agricultural Sciences, Hangzhou, 311799, China

5 School of Plant Protection, Hainan University, Haikou 570228, China 
silkworms, which is the most traditional and direct utilization of mulberry. Mulberry leaves were recorded as antibacterial and anti-inflammatory medicines by ancient Chinese pharmacopoeias, such as the Compendium of Material Medica and Shennong Materia Medica (Yu et al. 2018). With the rapid development of modern medicine and pharmacies, many studies have indicated that mulberry leaves have health effects, including antioxidant (Zhang et al. 2018a, b, c; Ma et al. 2018) and anti-inflammatory effects (Thabti et al. 2013; Gryn-Rynko et al. 2016), which can be used to improve eyesight, protect against liver damage (Yang et al., 2010), lower blood glucose, lower lipids (Liu et al. 2008; Ranjan et al. 2017; Li et al. 2017; Chang et al. 2016) and lower fat metabolism (Hyunbok et al. 2017). Therefore, the Ministry of Health of China has listed mulberry leaves as a plant resource that is "a source of both medicine and food". Mulberry leaves have been developed into many foods, such as mulberry leaf tofu (Kim et al. 2008), mulberry leaf biscuits (Monika et al. 2016), mulberry leaf tea (Sheng et al. 2018) and mulberry leaf dishes (Kim et al. 2018). Among them, mulberry leaf tea is the most popular mulberry leaf food. Mulberry leaf tea includes bud tea and leaf tea. Leaf tea is usually derived from ordinary leaves, because it is not limited by materials, its output meets the supply. However, the materials of bud tea are derived from one bud and two leaves from the top of mulberry shoots (leaf bud and the two leaves immediately below it), and the production of bud tea is limited due to the precise requirements for these rare raw materials. Bud tea is a particularly valuable mulberry tea products sold on the market. Due to the increased demand for bud tea, new buds of mulberry seedlings are severely lacking, resulting in a shortage of supplies in markets $(\mathrm{Li}$ et al. 2019; Hu et al. 2020). Therefore, it is necessary to increase the output and medicinal ingredients of mulberry leaves by exogenous hormone regulation.

Plant hormones play critical roles in plant growth and differentiation as well as the accumulation of medicinal ingredients (Marı́n et al. 2001; Liu et al. 2018; He et al. 2018). Plant hormones increase the expression of related enzyme genes in the secondary metabolite synthesis pathway, thereby increasing enzyme activity and ultimately increasing the accumulation of secondary metabolites. For example, melatonin treatment maintains higher glucosinolates in broccoli, and increases the percentage of glucoraphanin, the most potent anticarcinogenic agent (Miao et al. 2020). Moreover, the content of phenolic compounds in Jujube is increased by melatonin treatment (Wang et al. 2020). Previous results have shown that exogenous hormones can control the new shoot bud and accumulation of medicinal ingredients in plants, especially traditional Chinese medicinal plants ( $\mathrm{He}$ et al. 2014; Halim et al. 2017; Salerno et al. 2017). 6-Benzylaminopurine (6-BA) is a safe and efficient synthetic cytokinin mainly used for increasing productivity to promote undifferentiated tissue differentiation and lateral bud outgrowth (Sprent et al. 1967). 6-BA application directly promotes lateral bud growth. For example, Liu et al. (2009) reported that 6-BA stimulates the outgrowth of wheat tiller buds. Similarly, foliar spray application of 6-BA promotes the outgrowth of lateral buds in jatropha (Jatropha curcas) and nursery apple trees (Elfving et al. 2006; Ni et al. 2015).

However, the effects of 6-BA on the differential growth and contents of medicinal ingredients in mulberry seedlings are unknown. In our previous experiment, eight different concentrations of 6-BA were evaluated using preliminary field trials, and optimal results were obtained when mulberry leaves were treated with $30 \mathrm{mg} / \mathrm{L}$ 6-BA. The new shoots and buds of mulberry seedlings treated with $30 \mathrm{mg} / \mathrm{L}$ 6-BA were higher than those of seedlings treated with other concentrations of 6-BA, indicating that the optimal concentration of $6-\mathrm{BA}$ of $30 \mathrm{mg} / \mathrm{L}$. In the present study, we used $30 \mathrm{mg} / \mathrm{L}$ 6-BA solution to treat mulberry seedlings, and we determined the growth, chlorophyll contents, soluble sugar contents, malonaldehyde (MDA) contents, antioxidant (POD) levels, superoxide dismutase (SOD) activity levels, flavonoid accumulation and expression of enzyme-related genes involved in the flavonoid synthesis pathway. According to the maximum residue limit (MRL) of 6-BA and the current European Union standard of acceptable daily intake (ADI) as well as the average body weight (bw) and daily intake of food in different age groups in China, the dietary risk of 6-BA was assessed by calculating the estimated daily intake (EDI) and the risk quotient (RQ). Among them, the maximum residue limit (MRL) of 6-BA was $0.2 \mathrm{mg} / \mathrm{kg}$ (https:// www.legislation.gov.au/Details/F2017C01208), and the acceptable daily intake (ADI) was $0.01 \mathrm{mg} /(\mathrm{kg} \mathrm{bw} \cdot \mathrm{d}$ ) (European Food Safety Authority 2020). The results showed that application of $30 \mathrm{mg} / \mathrm{L} 6-\mathrm{BA}$ did not cause higher dietary risk.

\section{Materials and Methods}

\section{Plant Material}

Mulberry seedings of "Gui sang you 62" (GSY62) (Morus alba L.) with no physiological damage or microbial infection were kindly supplied by Zhejiang Haining Changxin Mulberry Planting Base, Zhejiang, China. Some mulberry seedlings were planted in the outdoor field to screen the concentration of 6-BA, and other mulberry seedings were planted in a greenhouse to analyze the gene expression of key enzymes in growth, physiological indexes, flavonoids, gene expression of key enzymes in the flavonoid biosynthesis pathway and dietary risk assessment.

GSY62 mulberry seedlings were grown in plastic pots in a greenhouse with vermiculite and turf soil (1:3) at the 
College of Food Science and Engineering, Hainan University, Haikou, Hainan, China $\left(20^{\circ} 03^{\prime} 39\right.$ N; $110^{\circ} 19^{\prime} 9$ E). The average (minimum-maximum) relative humidity and temperature were $63-82 \%$ and $27-34{ }^{\circ} \mathrm{C}$, respectively, and no rainfall was reported during the trial period.

\section{Field Efficacy Test to Screening for the Optimal Concentration of 6-BA}

We tested 8 concentrations of 6-BA solution in the field. Different concentrations $(10,20.30,40,50,60,600$, and $1800 \mathrm{mg} / \mathrm{L}$ ) of 6-BA solution were prepared by adding solute into distilled $\mathrm{H}_{2} \mathrm{O}$, and the mixture was stirred until dissolution. A surfactant was included in all solutions at $0.5 \mathrm{~g} / \mathrm{L}$ (Jiexiaoli, Organosilicone adjuvants, Hexion, USA). When 2 to 3 new bud leaves grew on the main stem of mulberry seedlings, 8 concentrations of 6-BA solution (including $0.5 \mathrm{~g} / \mathrm{L}$ surfactant) were immediately sprayed at the volume of $4.8 \pm 0.1 \mathrm{~mL}$ per plant on all leaves. The control mulberry seedlings were sprayed with distilled water containing the same amount of surfactant at the same time, and the spraying volume for each plant was $4.8 \pm 0.1 \mathrm{~mL}$. Each treatment group included 200 mulberry seedlings. After treatment, all mulberry seedlings were irrigated every $2 \mathrm{~d}$, and each plant was irrigated with $500-600 \mathrm{~mL}$ water. Ten days after application, the numbers of new buds and branches of mulberry seedlings treated with different concentrations of 6-BA were compared and analyzed. The optimum concentration of 6-BA was then selected. One treatment for each concentration was applied, and each treatment was replicated 3 times in a completely randomized design.

\section{New Shoots and Buds of Mulberry Seedlings after Treatment}

When 2 to 3 new bud leaves grew on the main stem of mulberry seedlings, $30 \mathrm{mg} / \mathrm{L}$ 6-BA solution (including $0.5 \mathrm{~g} / \mathrm{L}$ surfactant) was immediately sprayed at the volume of $4.8 \pm 0.1 \mathrm{~mL}$ per plant on all leaves. The control mulberry seedlings were sprayed with distilled water containing the same amount of surfactant at the same time, and the spraying volume for each plant was $4.8 \pm 0.1 \mathrm{~mL}$. After treatment, all mulberry seedlings were irrigated every $2 \mathrm{~d}$, and each plant was irrigated with $500-600 \mathrm{~mL}$ water. According to the optimal harvest time of mulberry leaf bud tea (within one month after mulberry leaf germination), mulberry leaves were harvested (Gu et al. 2010; Zhou 2015). Mulberry leaves were collected at $0 \mathrm{~d}, 5 \mathrm{~d}, 10 \mathrm{~d}, 15 \mathrm{~d}, 20 \mathrm{~d}, 25 \mathrm{~d}$ and 30 $\mathrm{d}$ after spraying, and the number of new shoots, number of buds, physiological indexes and flavonoid contents were determined. A new shoot refers to the new branch of the main branch. The new shoots and buds of 150-200 mulberry seedlings were determined in each treatment. All treatments were sprayed only once and each treatment was replicated 3 times in a completely randomized design.

\section{Determination of Chlorophyll Content}

Approximately, $0.02 \mathrm{~g}$ of mulberry leaf sample was added to $5 \mathrm{~mL}$ of $80 \%$ ice-cold acetone. The mixtures were rapidly ground until homogenized and then centrifuged at $5000 \mathrm{rpm}$ for $5 \mathrm{~min}$ at $4{ }^{\circ} \mathrm{C}$. The absorbance of the supernatant was measured spectrophotometrically at 475, 645 and $663 \mathrm{~nm}$ with a spectrophotometer (Lichtenthaler et al. 1987). Chl $(a+b)$ content was estimated as $\mathrm{mg} / \mathrm{g}$ fresh weight $(\mathrm{FW})$.

\section{Determination of MDA Content}

A MDA content kit from the Nanjing Jiancheng Bioengineering Institute (Nanjing, China) was used to determine the MDA content, and the absorbance at $530 \mathrm{~nm}$ was determined. The MDA contents of mulberry leaves were expressed on a fresh weight basis.

\section{Measurement of Soluble Sugar Content}

Fresh mulberry leaf samples $(0.1 \mathrm{~g})$ were placed into $1.5 \mathrm{~mL}$ centrifuge tubes, and $1 \mathrm{~mL}$ of distilled water was added to each tube. The mixtures were ground into homogenates, and the samples were placed in boiling water for $10 \mathrm{~min}$. After cooling, the samples were centrifuged at $4000 \mathrm{rpm}$ for $10 \mathrm{~min}$ at room temperature. A soluble sugar content kit from the Nanjing Jiancheng Biological Engineering Institute (Nanjing, China) was used to determine the soluble sugar contents, and the absorbance at $620 \mathrm{~nm}$ was determined. Soluble sugar was estimated as $\mathrm{mg} / \mathrm{g}$ fresh weigh (FW).

\section{Measurement of SOD and POD Activities}

Mulberry leaf samples $(0.1 \mathrm{~g})$ were prepared from mulberry seedlings. SOD and POD kits were obtained from the Nanjing Jiancheng Bioengineering Institute (Nanjing, China) to detect changes in the SOD and POD activities at an absorbances of $550 \mathrm{~nm}$ and $420 \mathrm{~nm}$, respectively.

\section{Analysis of Flavonoids}

Dried mulberry leaves were crushed and sifted through a 40-mesh screen to obtain mulberry leaf powder. One gram of mulberry leaf powder was weighed and transferred to a $50 \mathrm{~mL}$ Erlenmeyer flask containing $25 \mathrm{~mL}$ of $70 \%$ methanol. The flavonoids of the mulberry leaf powder were extracted by ultrasonication for $30 \mathrm{~min}$ and filtration through a $0.22 \mu \mathrm{m}$ micropore membrane. A $10 \mu \mathrm{L}$ aliquot of the supernatant was analyzed on a normal-phase high-performance 
liquid chromatography (HPLC) apparatus (model LC-20AD, Shimadzu, Japan) equipped with a CNWSIL C18 column $(4.6 \times 250 \mathrm{~mm}, 5 \mu \mathrm{m}$; CNW, Shanghai, China) and ultraviolet detector. The acetonitrile and formic acid aqueous solution was delivered at $0.8 \mathrm{~mL} / \mathrm{min}$. Calibration curves of pure standards were used to quantify rutin (Rut), chlorogenic acid (ChA), isoquercitrin (IQ) and astragalin (Ast). References for Rut (98\% purity, Shanghai YuanYe Bio-Technology Co., Ltd., no. B20771), ChA (98\% purity, Shanghai YuanYe BioTechnology Co., Ltd., no. B20782), IQ (98\% purity, Shanghai YuanYe Bio-Technology Co., Ltd., no. B21529) and Ast (98\% purity, Shanghai YuanYe Bio-Technology Co., Ltd., no. B21704) were analytical standards. Liquid chromatography-grade methanol (LiChrosolv, Shanghai, China) was used as the solvent. The peaks of the flavonoid standards (Rut, ChA, IQ, and Ast) were distinguished by their retention times, and the peak area was substituted into the standard curve. The flavonoid content data were expressed as $\mu \mathrm{g} / \mathrm{g}$ of DW.

\section{Determination of 6-BA Dietary Risk Assessment}

Samples of mulberry leaves were collected at 5, 7, 10 and $14 \mathrm{~d}$ after the control treatment (untreated samples) and $30 \mathrm{mg} / \mathrm{L}$ 6-BA treatment, and the residues of 6-BA were determined. Samples $(10.00 \pm 0.01 \mathrm{~g})$ were placed in $50 \mathrm{~mL}$ centrifuge tubes, and a $10 \mathrm{~mL}$ solution containing $1 \%(\mathrm{v} / \mathrm{v})$ acetic acid in acetonitrile was added; the mixture was homogenized for $2 \mathrm{~min}$. Dehydration reagents (4 $\mathrm{g}$ of anhydrous magnesium sulfate and $1.5 \mathrm{~g}$ of sodium acetate) were then added, and the mixture was submitted to vortex oscillation for $1 \mathrm{~min}$ and centrifugation at $4000 \mathrm{r} / \mathrm{min}$ for $3 \mathrm{~min}$. Clear liquid $(2.0 \mathrm{~mL})$ was obtained in a dispersive solid-phase extraction tube ( $25 \mathrm{mg}$ of $\mathrm{C} 18$ and $150 \mathrm{mg}$ of anhydrous magnesium sulfate). The liquid was vortexed for $1 \mathrm{~min}$ after centrifugation at $16,000 \mathrm{r} / \mathrm{min}$ for $5 \mathrm{~min}$, and the obtained supernatant was filtered through by a $0.22 \mu \mathrm{m}$ organic filter membrane for the detection of 6-BA residue. The sample pretreatment method mentioned above refers to the method of Huang et al (2014), while the HPLC method is optimized on the basis of Huang et al (2014). The specific procedures are described below.

Chromatographic determination was performed with HPLC (model LC-20AD, Shimadzu, Japan) using a gradient condition with mobile phases A $(5 \mathrm{mmol} / \mathrm{L}$ ammonium acetate $+0.05 \%$ formic acid) and $\mathrm{B}$ (acetonitrile chromatographic grade) at a flow rate of $0.5 \mathrm{~mL} / \mathrm{min}$. The isocratic elution program was set as $25 \% \mathrm{~B}(0.01-30 \mathrm{~min})$, and the injection volume was $5 \mu \mathrm{L}$. The analytic column was a CNWSIL C18 column $(4.6 \times 250 \mathrm{~mm}, 5 \mu \mathrm{m}$; CNW, Shanghai, China) equipped with an ultraviolet detector (model
SPD-20A, Shimadzu, Japan). 6-BA (98\% purity, Shanghai YuanYe Bio-Technology Co., Ltd., no. B24213) standard was provided by Shanghai YuanYe and was prepared as a $100 \mathrm{mg} / \mathrm{L}$ reserve solution with methanol and stored at $-4{ }^{\circ} \mathrm{C}$. Acetonitrile was diluted to $3.125,6.25,12.5,25$, 50 and $100 \mathrm{mg} / \mathrm{L}$ and quantified by the external standard method. Risk assessment of 6-BA in mulberry leaves was performed according to the method of Dong et al. (2017).

The following equations were used to assess the risk of mulberry intake in adults (RQ) and estimated daily intake (EDI).

$E D I=(F \times S T M R) /$ mean body weight $(b w)$

$R Q=E D I / A D I$

where EDI is the estimated daily intake ( $\mathrm{mg} / \mathrm{kg} \mathrm{bw}) ; \mathrm{F}$ is the daily food intake $(\mathrm{kg} / \mathrm{d})$; STMR is the residual medium concentration $(\mathrm{mg} / \mathrm{kg})$; RQ is the risk quotient; and ADI is the allowable daily intake ( $\mathrm{mg} / \mathrm{kg} \mathrm{bw})$.

\section{Expression Analysis of Key Genes Involved in Flavonoid Biosynthesis by Real-time Quantitative PCR (RT-qPCR)}

Genes control the metabolic process by controlling the synthesis of enzymes and then regulating the traits of organisms. Because the level of metabolites in organisms lags the expression of genes, it is necessary to determine the gene expression level before the appearance of the trait. Because the level of gene expression after hormone treatment was instantaneous, RT-qPCR was used to analyze the expression of key enzyme genes in the flavonoid biosynthesis pathway of mulberry buds at $2 \mathrm{~h}, 3 \mathrm{~h}, 6 \mathrm{~h}, 12 \mathrm{~h}, 24 \mathrm{~h}, 48 \mathrm{~h}, 72 \mathrm{~h}$ and $96 \mathrm{~h}$ after the control treatment and $30 \mathrm{mg} / \mathrm{L} \mathrm{6-BA}$ treatment. One bud and two leaves of a mulberry seeding were harvested for RNA extraction according to the RNA Simple Total RNA Kit instructions (Tiangen, Beijing, China). First strand cDNA was synthesized with RHiScript III RT SuperMix for qPCR (Vazyme, Nanjing, China). Relative transcript levels of target genes were analyzed using the $2^{-\Delta \Delta \mathrm{Ct}}$ method (Schmittgen and livak, 2008). All primer pairs used for RTqPCR analyses of mulberry leaves are listed in Table 1.

\section{Statistical Analysis}

Data were analyzed with IBM-SPSS 25.0 statistical software (IBM Corporation, USA). The differences were examined by two-factor analysis of variance (ANOVA), followed by least significant difference (LSD) tests $(P \leq 0.05)$. The 
Table 1 All primer pairs used for RT-qPCR analyses of mulberry leaves

\begin{tabular}{|c|c|}
\hline The name of the gene & Primer sequences \\
\hline Phenylalanine (PAL) & $\begin{array}{l}\text { F: 5' TGCTACCTACCCGCTGATGC 3' } \\
\text { R: 5' GCTCGTATTCTTCTCGCTTTCG 3, }\end{array}$ \\
\hline 4-xoumarate-CoA ligase (4CL) & $\begin{array}{l}\text { F: 5' CAAGGGAGTCATCCTAACTCACAA 3' } \\
\text { R: 5' GGCAGAACGCATAGAAACACG 3' }\end{array}$ \\
\hline Chalcone synthase (CHS) & $\begin{array}{l}\text { F: 5' CTCGGGATCAGCGACTGGA 3' } \\
\text { R: 5' GTGGCCCTCAGCTTCTCCTT 3' }\end{array}$ \\
\hline Flavonoid 3-O-glucosyltransferase (F3GT) & $\begin{array}{l}\text { F: 5' CTCAGAAGCAAGAAACTGCCTAAA 3' } \\
\text { R: 5' CCTGCCTAGCAAAGGAAGTGG 3' }\end{array}$ \\
\hline$\beta$-actin & $\begin{array}{l}\text { F: 5' CCAAGAGCAGCAGTTCCTCGGTT 3' } \\
\text { R: CTCTGGTGGAGCAACAACCT 3' }\end{array}$ \\
\hline
\end{tabular}

values were reported using a three repetitions method with the standard deviation (SD).

\section{Results}

\section{Optimum Concentration of 6-BA for Mulberry Growth}

The effects of different concentrations of 6-BA on new buds and shoots of mulberry leaves are shown in Fig. 1. On the 10th day after treatment, the number of new branches and new buds of mulberry leaves treated with $30 \mathrm{mg} / \mathrm{L} 6-\mathrm{BA}$ was significantly higher than that of the control (0 mg/L 6-BA) and other concentrations of 6-BA. In addition, the number of new buds and branches of mulberry treated with 600 and $1800 \mathrm{mg} / \mathrm{L}$ 6-BA was significantly lower than that of the control.

\section{Growth Regulation in Mulberry Seedlings}

During the culture period of $0-30 \mathrm{~d}$, the number of new shoots and buds of mulberry seedlings gradually increased, and the number of new shoots of mulberry seedlings in the $30 \mathrm{mg} / \mathrm{L}$ 6-BA treatment group reached peak values at $15 \mathrm{~d}$ and was increased by $130 \%$ compared to the control treatment (Fig. 2C). Moreover, the number of buds of mulberry seedlings treated with $30 \mathrm{mg} / \mathrm{L}$ 6-BA reached peak values and was increased by $64 \%$ compared to the control treatment (Fig. 2D).

\section{Effect of 6-BA Treatment on Chlorophyll and Soluble Sugar Contents}

6-BA treatment increased the $\mathrm{Chl}(\mathrm{a}+\mathrm{b})$ content in the initial stage compared to the control. The $\mathrm{Chl}(\mathrm{a}+\mathrm{b})$ content was significantly higher in 6-BA-treated samples than in control samples within $25 \mathrm{~d}$ after treatment (Fig. 3A). The $\mathrm{Chl}(\mathrm{a}+\mathrm{b})$ content in both the control and 6-BA treatment groups reached the maximum value at $15 \mathrm{~d}$ when the $\mathrm{Chl}$ $(\mathrm{a}+\mathrm{b})$ content in the 6-BA treatment was 1.1-fold higher than the control.

As shown in Fig. 3B, the content of soluble sugar in mulberry leaves increased with growth in the $30 \mathrm{mg} / \mathrm{L}$ 6-BA-treated samples. In addition, compared to the control, the $30 \mathrm{mg} / \mathrm{L} 6-\mathrm{BA}$ treatment significantly increased the accumulation of soluble sugar to $50.90 \mathrm{mg} / \mathrm{g} \mathrm{FW}$ after $30 \mathrm{~d}$ of growth, and the soluble sugar content after 6-BA treatment was 1.56-fold higher than the control from 15 to $30 \mathrm{~d}$. However, the soluble sugar content of mulberry leaves treated with $30 \mathrm{mg} / \mathrm{L}$ 6-BA was significantly lower than the control from 0 to $15 \mathrm{~d}$.
Fig. 1 Effects of the control $(0 \mathrm{mg} / \mathrm{L} 6-\mathrm{BA})$ and different concentrations of 6-BA treatment on the number of new shoots (A) and buds (B) of mulberry seedlings. Measurements were made 10 days after treatment. Each value represents the mean \pm SD of three replicates. Values not sharing a common letter are significantly different at $P \leq 0.05$
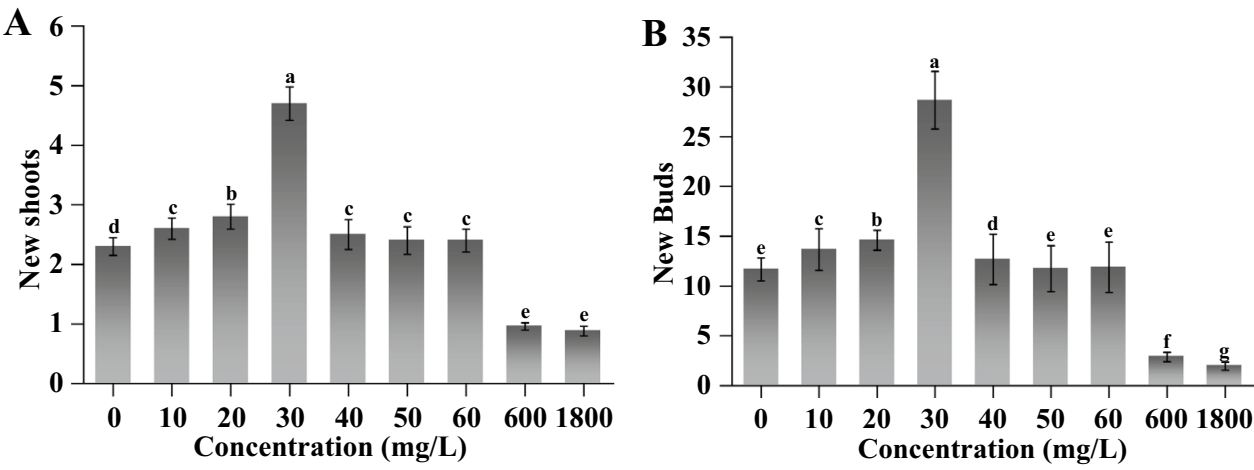

and $30 \mathrm{mg} / \mathrm{L}$ 6-BA treatment (B) on seedling growth. Effects of $30 \mathrm{mg} / \mathrm{L}$ 6-BA treatment on the number of new shoots $(\mathbf{C})$ and buds (D) of mulberry seedings. Data were collected at 0 , $5,10,15,20,25$ and $30 \mathrm{~d}$ after treatment. Each value represents the mean \pm SD of three replicates. Values not sharing a common letter are significantly different at $P \leq 0.05$
Fig. 2 Effects of the control (A)

A
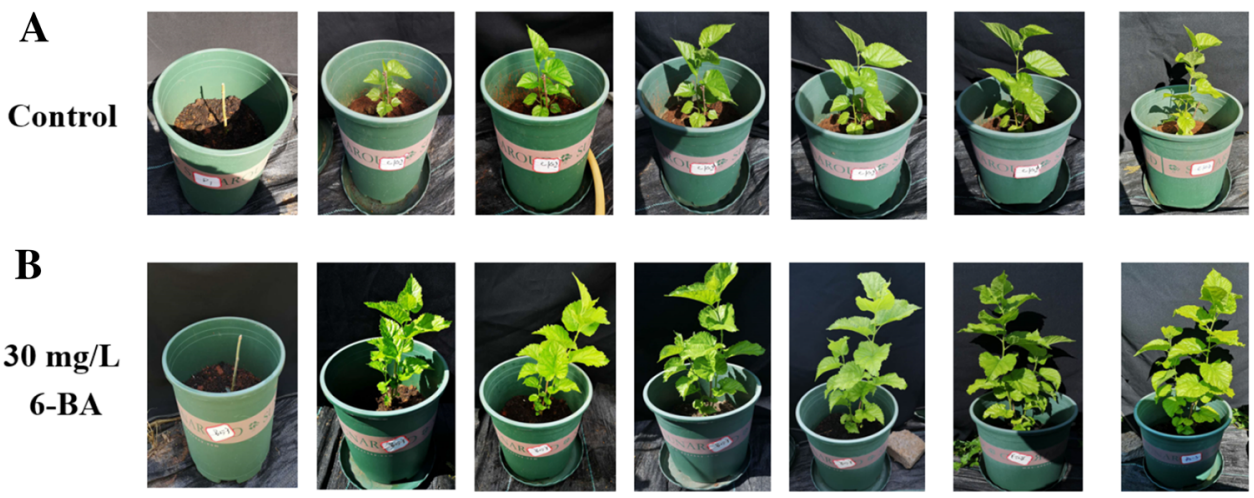

C
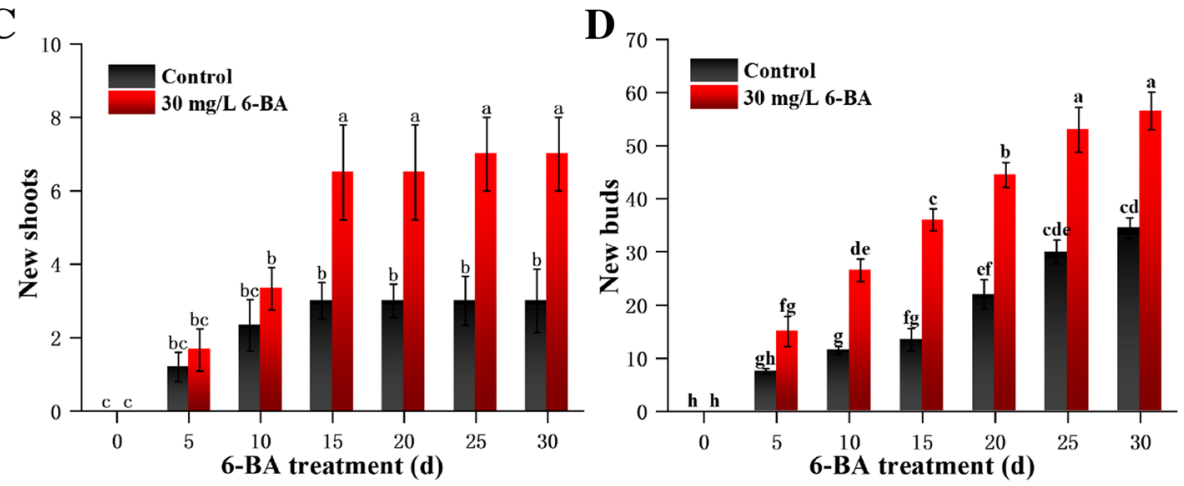

Fig. 3 Effects of $30 \mathrm{mg} / \mathrm{L}$ 6-BA treatment on the contents of chlorophyll $(\mathrm{a}+\mathrm{b})(\mathbf{A})$ and soluble sugar $(\mathbf{B})$ in mulberry leaves. Data were collected at 0 , $5,10,15,20,25$ and $30 \mathrm{~d}$ after treatment. Each value represents the mean \pm SD of three replicates. Values not sharing a common letter are significantly different at $P \leq 0.05$
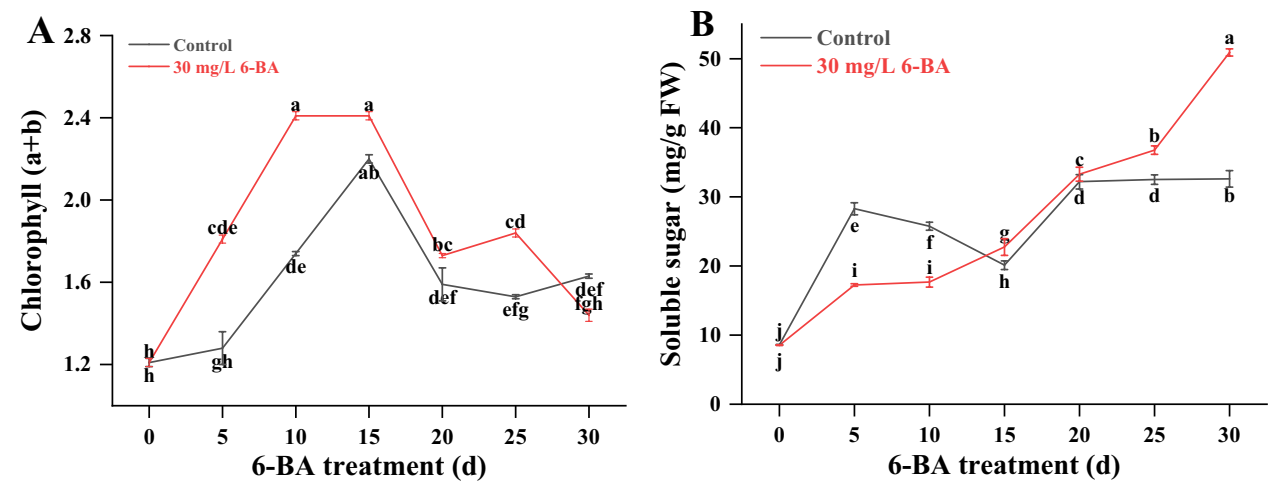

\section{Effect of 6-BA Treatment on the MDA Content, SOD Activity and POD Activity}

MDA is one of the most important products of membrane lipid peroxidation, but its production can also aggravate membrane damage (Wang 2014). Therefore, the MDA content is a common indicator used in plant physiology research. As shown in Fig. 4A, the MDA content in mulberry leaves in the control group reached a peak at $20 \mathrm{~d}$ when it was significantly higher than in the 6-BA treatment with a 2.21-fold increase compared to the 6-BA treatment.

The SOD and POD plant enzymes protect plant cells from damage induced by reactive oxygen species (ROS), reducing damage to the cell membrane. Thus, the SOD and POD activity levels in plants play a vital role in plant growth. In the present study, the enzyme activity levels of SOD and POD were determined by spectrophotometry. The results revealed that the SOD activity of mulberry leaves in the 6-BA treatment gradually increased and reached its maximum value at $30 \mathrm{~d}$. The levels of SOD activity in mulberry leaves treated with $30 \mathrm{mg} / \mathrm{L} \mathrm{6-BA}$ were increased by $60 \%$ compared to the control (Fig. 4B). The levels of POD activity in the 6-BA treatment and control groups showed an overall increasing trend, and the POD activity in the 6-BA treatment group was significantly higher than that in the control group within $20 \mathrm{~d}$ (Fig. 4C). After culturing for 5, 10, 15 and $20 \mathrm{~d}$, the POD activities in mulberry leaves treated with $30 \mathrm{mg} / \mathrm{L}$ 6-BA were increased by $7 \%, 22 \%, 7 \%$ and $10 \%$ compared to the control, respectively. 

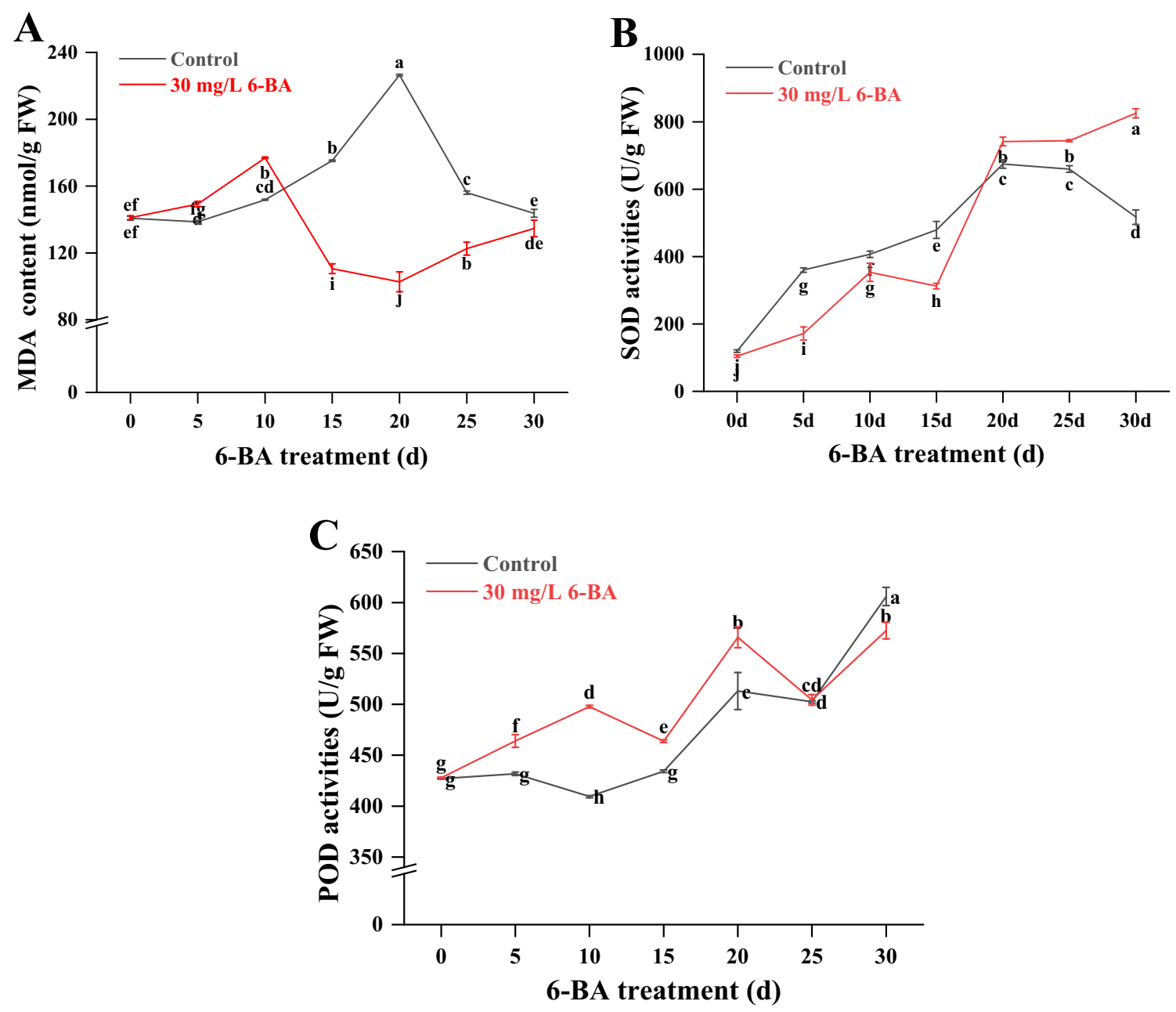

Fig. 4 Effects of $30 \mathrm{mg} / \mathrm{L}$ 6-BA treatment on the contents of MDA (A), SOD (B) and POD (C) in mulberry leaves. Data were collected at $0,5,10,15,20,25$ and $30 \mathrm{~d}$ after treatment. Each value represents

\section{Effect of 6-BA on Mulberry Flavonoids}

During the culture period of $0-30 \mathrm{~d}$, the contents of Rut, IQ, and Ast in the leaves of mulberry seedlings treated with $30 \mathrm{mg} / \mathrm{L}$ 6-BA gradually increased and then decreased, and they reached maximum values at $20 \mathrm{~d}$. After culturing for $20 \mathrm{~d}$, the highest contents of Rut, IQ, and Ast in mulberry leaves treated with 6-BA treatment were $0.127,0.120$, and $0.050 \mathrm{mg} / \mathrm{g} \mathrm{DW}$, which were 4.6 fold, 12.36-fold and 7.24-fold higher than the contents at 0 $\mathrm{d}$ and increased by $25.87 \%, 41.31 \%$ and $57.31 \%$ compared to the contents in the control at $20 \mathrm{~d}$, respectively (Fig. 5A, $5 \mathrm{~B}$ and $5 \mathrm{C}$ ). The ChA content in mulberry leaves treated with 6-BA reached a peak value at $5 \mathrm{~d}$ with a ChA content 1.25 -fold higher than that of the control (Fig. 5D). the mean \pm SD of three replicates. Values not sharing a common letter are significantly different at $P \leq 0.05$

\section{Risk Assessment of 6-BA in Mulberry Leaves}

The terminal residue levels in mulberry leaves after one application of $30 \mathrm{mg} / \mathrm{L}$ 6-BA solution are listed in Table 2. The pesticide residues in mulberry leaves ranged from 0.1540 to $0.1701 \mathrm{mg} / \mathrm{kg}$ at $5 \mathrm{~d}$, and the STMR of 6-BA was $0.1691 \mathrm{mg} / \mathrm{kg}$. Additionally, no 6-BA residue was detected in the control mulberry leaves at $5 \mathrm{~d}, 7 \mathrm{~d}, 10 \mathrm{~d}$ and $14 \mathrm{~d}$. According to the existing ADI published by the European Union, the ADI of 6-BA is $0.01 \mathrm{mg} / \mathrm{kg}$ bw. Considering the average weight of different age groups in China and the daily intake of vegetables, the EDI and RQ of 6-BA were calculated and are shown in Table 3. In general, a RQ greater than 1 indicates a large impact on consumer health. In this study, the highest RQ of 6-BA application was 0.1668 , which is far 

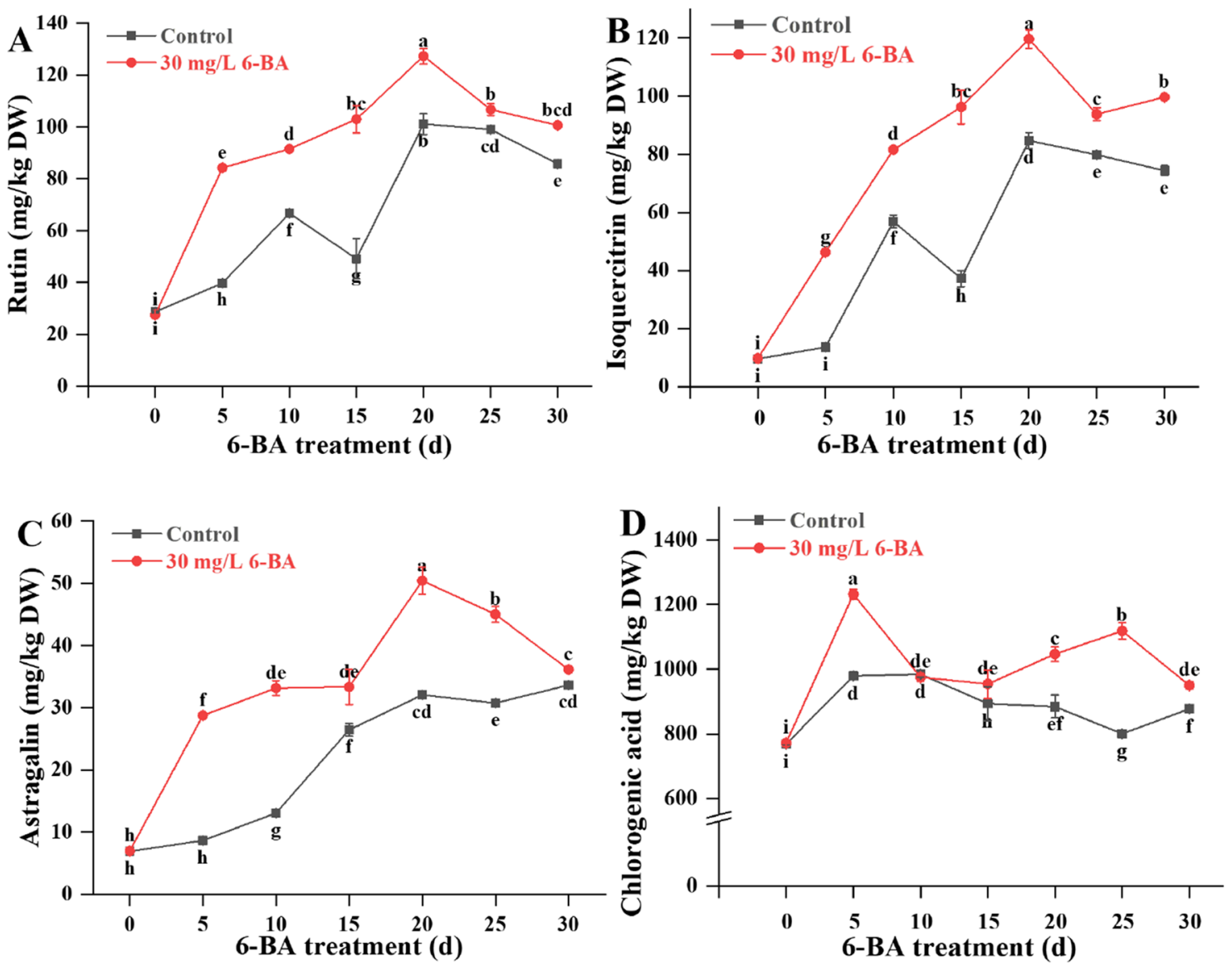

Fig. 5 Effects of $30 \mathrm{mg} / \mathrm{L}$ 6-BA treatment on the contents of rutin (A), Isoquercitrin (B), Astragalin (C) and Chlorogenic acid (D) in mulberry leaves. Data were collected at $0,5,10,15,20,25$ and 30

Table 2 The residue limit of 6-BA in mulberry leaves

\begin{tabular}{lllll}
\hline Chemical & $\begin{array}{l}\text { Spraying } \\
\text { dose } \\
(\mathrm{mg} / \mathrm{L})\end{array}$ & $\begin{array}{l}\text { Days after } \\
\text { forward } \\
\text { spraying } \\
(\mathrm{d})\end{array}$ & $\begin{array}{l}\text { Residues } \\
(\mathrm{mg} / \mathrm{kg})\end{array}$ & $\begin{array}{l}\text { Maximum } \\
\text { residue limit } \\
(\mathrm{MRL})(\mathrm{mg} /\end{array}$ \\
$\mathrm{kg})$
\end{tabular}

Note: "—" means not checked out

MRL established by European Commission (2005)

lower than 1. In the present study, the dietary intake data of tea consumers used for risk assessment were obtained from the country with the highest per capita tea consumption in the world, namely the UK, where tea consumption is $13 \mathrm{~g}$ per person per day. The average per capita weight (BW) was calculated as $60 \mathrm{~kg}$, and the RQ value was $1.4972 \times 10^{-6}$, which is far less than 1 (Table 4$)$. These results indicated that the use of 6-BA in the present study was safe. Moreover, $\mathrm{d}$ after treatment. Each value represents the mean \pm SD of three replicates. Values not sharing a common letter are significantly different at $P \leq 0.05$

Table 3 Risk assessment of 6-BA in mulberry leaves

\begin{tabular}{lllll}
\hline Age & $\begin{array}{l}\text { Body } \\
\text { weight }(\mathrm{kg})\end{array}$ & $\begin{array}{l}\text { Consumption of } \\
\text { vegetable } \\
(\mathrm{g} / \mathrm{d})\end{array}$ & $\begin{array}{l}\text { EDI } \\
(\mu \mathrm{g} /(\mathrm{kg} \mathrm{bw})) \\
6-\mathrm{BA}\end{array}$ & 6-BA \\
& & & $5 \mathrm{~d}$ & $5 \mathrm{~d}$ \\
\hline $2-3$ & 12.7 & 125.1 & 0.0017 & 0.1666 \\
$4-6$ & 16.5 & 162.8 & 0.0017 & 0.1668 \\
$7-10$ & 22.3 & 206.5 & 0.0016 & 0.1566 \\
$11-13$ & 34.05 & 235.85 & 0.0012 & 0.1171 \\
$14-17$ & 45.95 & 255.35 & 0.0009 & 0.0940 \\
$18-29$ & 55.25 & 286.05 & 0.0009 & 0.0875 \\
$30-44$ & 60.3 & 297.15 & 0.0008 & 0.0833 \\
$45-59$ & 60.05 & 304.95 & 0.0009 & 0.0859 \\
$60-69$ & 57.95 & 278.75 & 0.0008 & 0.0813 \\
$\geq 70$ & 54.75 & 248.9 & 0.0008 & 0.0769 \\
\hline
\end{tabular}

no pesticide residues were detected in mulberry leaves 7-14 $\mathrm{d}$ after $30 \mathrm{mg} / \mathrm{L}$ 6-BA was applied, indicating that the safe interval for the use of 6-BA on mulberry trees is $7 \mathrm{~d}$. In 
Table 4 Risk assessment of 6-BA in mulberry leaf tea

\begin{tabular}{llll}
\hline $\begin{array}{l}\text { Body weight } \\
(\mathrm{kg})\end{array}$ & $\begin{array}{l}\text { Consumption of tea } \\
(\mathrm{g} / \mathrm{d})\end{array}$ & $\begin{array}{l}\text { EDI (ng / (kg bw)) } \\
6-\mathrm{BA}\end{array}$ & $\begin{array}{l}\text { RQ } \\
6-\mathrm{BA}\end{array}$ \\
& & $5 \mathrm{~d}$ & $5 \mathrm{~d}$ \\
\hline 60 & 13 & 0.0150 & 0.0015 \\
\hline
\end{tabular}

many regions of China, mulberry leaves are used not only as food but also as animal feed. Therefore, the residual amount of 6-BA in mulberry leaves in the present study is appropriate for the multipurpose use of these leaves. Moreover, $30 \mathrm{mg} / \mathrm{L}$ 6-BA treatment provides a new method to improve the medicinal quality and development of high-value mulberry leaf foods.

\section{Effect of 6-BA Treatment on the Expression Levels of Flavonoid-related Genes}

According to the above results, $30 \mathrm{mg} / \mathrm{L}$ 6-BA plays a role in flavonoid accumulation in mulberry leaves during growth. Thus, RT-qPCR was used to analyze the expression of key enzyme genes in the flavonoid biosynthesis pathway of mulberry buds at $2 \mathrm{~h}, 3 \mathrm{~h}, 6 \mathrm{~h}, 12 \mathrm{~h}, 24 \mathrm{~h}, 48 \mathrm{~h}$, $72 \mathrm{~h}$ and $96 \mathrm{~h}$ after the control treatment and $30 \mathrm{mg} / \mathrm{L}$ 6-BA treatment. Phenylalanine ammonia lyase (PAL) (KJ616395.1), chalcone synthase (CHS) (KJ616398.1) and 4-coumarate-CoA ligase (4CL) (KJ616397.1) are important upstream enzyme genes regulating the flavonoids of mulberry leaves, while flavonoid 3-O-glucosyltransferase (F3GT) exclusively modulates flavonol biosynthesis genes (KJ616402.1) (Zhao et al., 2015). As shown in Fig. 6, the relative gene expression of $M a 4 C L$ and $M a P A L$ in the 6-BA treatment showed a trend of first increasing and then decreasing with a peak at $2 \mathrm{~h}$ and $3 \mathrm{~h}$, respectively. The relative expression levels of Ma4CL and MaPAL were 3.17 and 3.7, respectively, which were significantly higher than those in the control $(P \leq 0.05)$. As shown in Fig. 6, the relative expression levels of MaF3GT and MaCHS after $30 \mathrm{mg} / \mathrm{L} 6-\mathrm{BA}$ treatment were 4.99 and 42.34 at $6 \mathrm{~h}$ and $48 \mathrm{~h}$, respectively. All of the expression levels significantly higher than those of the control $(P \leq 0.05)$.
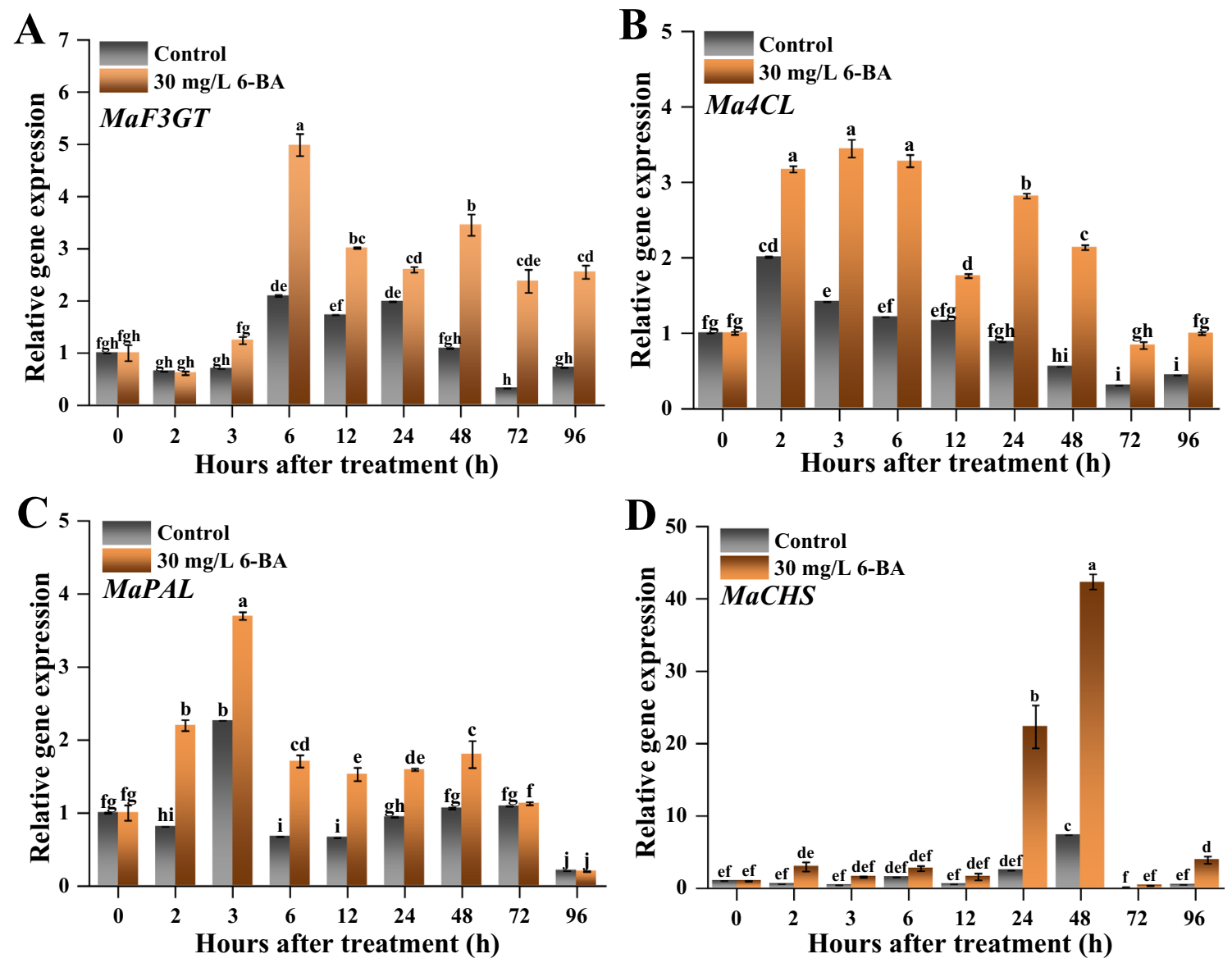

Fig. 6 Relative expression levels of F3GT, PAL, 4CL and CHS in mulberry leaves were treated with $30 \mathrm{mg} / \mathrm{L}$ 6-BA. Each value represents the mean $\pm \mathrm{SD}$ of three replicates. Values not sharing a common letter are significantly different at $P \leq 0.05$ 


\section{Discussion}

The preliminary experimental results of this study showed that $600 \mathrm{mg} / \mathrm{L}$ and $1800 \mathrm{mg} / \mathrm{L}$ 6-BA significantly inhibited the growth of mulberry leaves, indicating that a high concentration of 6-BA inhibits the growth of mulberry seedlings. Additionally, treatment with $30 \mathrm{mg} / \mathrm{L}$ 6-BA for $10 \mathrm{~d}$ significantly increaseed the number of new shoots and buds compared to the other treatments. Therefore, among the 8 concentrations, $30 \mathrm{mg} / \mathrm{L}$ 6-BA showed the best comprehensive effect, and the mulberry response to 6-BA is dependent on concentration. Based on these results, we concluded that 6-BA promotes the growth of mulberry seedlings. Similarly, several studies have also demonstrated that the appropriate concentration of 6-BA has a positive influence on plant differentiation and growth. For example, the application of $200 \mathrm{mg} / \mathrm{L}$ 6-BA significantly enhances the formation of productive lateral branches and increases the spring yield of tea plants (Camellia sinensis) compared to the control (Zhang et al. 2018a, b, c). The beneficial effects of 6-BA on plant differentiation and growth have been previously reported in Phellodendron amurense (Phellodendron chinense) seedlings and Indian sandalwood (Santalum album L.) seedlings (Liu et al. 2018; He et al. 2018). Similarly, acceleration of the flowering process has been observed using $200 \mathrm{mg} / \mathrm{L}$ 6-BA in orchid genera (Ngapui et al. 2014). Thus, these results suggest that the plant growth stage affects the interaction with 6-BA, resulting in different effects of 6-BA in different crops.

Chlorophyll a and chlorophyll $\mathrm{b}$ are the main pigments that absorb and transfer light energy, which improve the light capture efficiency (Melkozernov et al. 2006). Similarly, the development of new branches mainly depends on the photosynthesis provided by the leaves below the lateral branches (Ashley 1972). Moreover, the promotion of growth by 6-BA is usually accompanied by an increase in photosynthetic pigment content (Adedipe et al. 1971; Amin et al. 2007). Exogenous $30 \mathrm{mg} / \mathrm{L}$ 6-BA increased the chlorophyll content of mulberry leaves, enhanced photosynthesis and promoted the growth of mulberry leaves but did not cause stress. Soluble sugars are an important energy source in plant carbon metabolism, and the $30 \mathrm{mg} / \mathrm{L}$ 6-BA treatment significantly increased soluble sugar accumulation. However, at $0-15 \mathrm{~d}$, the soluble sugar content in mulberry leaves treated with $30 \mathrm{mg} / \mathrm{L}$ 6-BA was significantly lower than that of the control, which may be due to the sucrose yield in soluble sugar being related to the rate of photosynthesis (Kaur et al. 2007). Exogenous plant hormones promote leaf photosynthesis and improve carbon supply capacity (Gene 1993; Xia et al. 2009; Gao et al. 2017). The results showed that the chlorophyll content after the $30 \mathrm{mg} / \mathrm{L} 6-\mathrm{BA}$ treatment was significantly higher than that of the control at $0-15 d$, while the soluble sugar content of mulberry leaves treated with $30 \mathrm{mg} / \mathrm{L}$ 6-BA was significantly lower than that of the control at $0-15 \mathrm{~d}$. Sucrose in soluble sugar, as the main photosynthetic substance, provides carbon and energy for the growth of new buds from source tissue and channel storage tissue. In the vigorous growth period of new buds (0-15 d), improving the utilization rate of new buds is the basis of high yield (Fang et al. 2019).

During the process of metabolism, plants easily experience external stresses and produce large amounts of ROS. If ROS are not quickly cleared, they hamper growth and secondary metabolite production. Plants scavenge ROS through antioxidants (Alscher et al. 1997; Diplock et al. 1998; Mittler et al. 2002). Free radical action causes lipid peroxidation, and the oxidation end product is MDA. SOD and POD are the major components of the antioxidant system, and they play key roles in the growth processes of plants (Mittler et al. 2017; Yang et al. 2017). After culturing for $40 \mathrm{~d}$, $10 \mathrm{mg} / \mathrm{L}$ and $20 \mathrm{mg} / \mathrm{L}$ 6-BA increase the levels of POD and SOD in Phellodendron chinense seedlings ( $\mathrm{He}$ et al. 2018). After plants are sprayed with $30 \mathrm{mg} / \mathrm{L}$ 6-BA solution, the yield of super hybrid rice (Oryza sativa) is increased, and the SOD and POD activity levels are increased (Pan et al. 2013). In agreement with this, the present study also showed that $30 \mathrm{mg} / \mathrm{L} 6-\mathrm{BA}$ significantly reduced the accumulation of MDA in mulberry leaves. The main reason for this finding might be that $30 \mathrm{mg} / \mathrm{L}$ 6-BA effectively inhibited the accumulation of MDA by increasing the SOD and POD contents. In summary, treatment with $30 \mathrm{mg} / \mathrm{L}$ 6-BA did not induce stress, but it decreased the MDA content. In addition, the difference between SOD and POD had no effect on growth.

Flavonoids, such as Rut, ChA, IQ and Ast, are important functional bioactive compounds in mulberry and they have been reported to have many beneficial effects on human health, such as lowering blood glucose (Havsteen et al. 2002; Hamidullah et al. 2015; Testai et al. 2015) and improving immunity (Harborne et al. 1992) as well as having antiaging (Jo et al. 2009), antidiarrhea, antitussive, and expectorant effects (Mandal et al. 2010). Rut effectively improves blood glucose in patients with urinary disease by inhibiting intestinal carbohydrate absorption, reducing gluconeogenesis, increasing tissue glucose uptake, and stimulating pancreatic insulin secretion (Ahmed et al. 2010; Jadhav et al. 2012; Kappel et al. 2013). Mulberry leaves are a good source of Rut, which is used as a dietary supplement to prevent complications from diabetes. IQ effectively alleviates APAPinduced liver injury by inhibiting multiple mechanisms, such as oxidative stress and nitrosative stress induced by paracetamol (APAP) (Xie et al. 2015). Flavonoids from mulberry leaf extract efficiently protect human RBCs against free radical-induced oxidative damage. Among them, Ast has 
the greatest protective effect. In the present study, exogenous $30 \mathrm{mg} / \mathrm{L}$ 6-BA significantly increased the contents of Rut, IQ and Ast in the leaves of mulberry seedlings compared to the control and significantly increased the content of ChA compared to the control at $5 \mathrm{~d}$. Other studies have indicated that 6-BA at specific concentrations promotes the accumulation of medicinal ingredients. For example, He et al (2018) reported that 6-BA treatment significantly increases the contents of berberine and phellodendrine in Phellodendron chinense seedlings. Jessica et al (2019) reported that the extracts of Amburana cearensis (cumarú) treated with 6-BA during in vitro culture have higher flavonoid compound levels than extracts from plants cultured under traditional conditions. Xu et al (2012) reported that the contents of total phenols, glucosinolate, and sulforaphane in broccoli florets are significantly increased after treatment with 6-BA. Therefore, exogenous 6-BA plays a key regulatory role in the growth of different plants and the accumulation of medicinal ingredients (Choi et al. 2013).

$30 \mathrm{mg} / \mathrm{L}$ 6-BA not only increased the yield of mulberry buds, but also promoted the accumulation of flavonoids and improved the medicinal quality of mulberry buds. Therefore, it is necessary to explore the molecular mechanism of promoting the accumulation of flavonoids. PAL, CHS, 4CL and F3GT are considered key enzymes in the flavonoid synthesis pathway (Shih et al. 2008; Hodaei et al. 2018; He et al. 2020). In the present study, $30 \mathrm{mg} / \mathrm{L}$ 6-BA induced the expression of the MaF3GT, Ma4CL, MaPAL and MaCHS genes, which regulate flavonol synthesis. Similar to the present study, Liu et al (2019) reported that 6-BA significantly increases the content of anthocyanins in grape-fruits 110 $\mathrm{d}$ after flowering and significantly increases the expression levels of F3GT, CHS and PAL $90 \mathrm{~d}$ after flowering. Therefore, exogenous 6-BA may upregulate gene expression levels to promote the biosynthesis of flavonoids. In addition, several studies have reported that melatonin regulates key enzymes in phenol metabolism to maintain a high content of phenols during postharvest life. For example, melatonin induces PAL and CHS expression as well as enhances PAL and CHS activities, and it inhibits PPO activities and the expression level of related genes (Ma et al. 2016; Zhang et al. 2018a, b, c; Zheng et al. 2019). Both PAL and 4CL genes are key upstream genes of the flavonoid synthesis pathway. CHS is the key enzyme gene that provides the basic skeleton for flavonoid compounds, while F3GT is the last key enzyme gene for the formation of stable flavonols. In the present study, the expression levels of these four enzyme genes were significantly upregulated after treatment with $30 \mathrm{mg} / \mathrm{L}$ 6-BA.

In conclusion, we determined the effects of exogenous 6-BA on the growth, flavonoid compound contents and expression levels of key enzyme genes involved in the flavonoid synthesis pathway in mulberry seedlings. The results showed that exogenous $30 \mathrm{mg} / \mathrm{L}$ 6-BA significantly promoted the differentiation, growth and accumulation of flavonoids in mulberry leaves. Importantly, the present study showed that $30 \mathrm{mg} / \mathrm{L} 6-\mathrm{BA}$ significantly upregulated the expression of the key enzyme gene for flavonol synthesis. Moreover, mulberry leaves treated with $30 \mathrm{mg} / \mathrm{L}$ 6-BA conformed to food safety requirements. Nevertheless, further investigations are needed to clarify the regulatory mechanism by which 6-BA affects flavonoid synthesis.

Supplementary Information The online version contains supplementary material available at https://doi.org/10.1007/s00344-021-10435-x.

Acknowledgements We thank each of the authors of this article for their technical assistance.

Authors' Contributions All authors contributed to the study conception and design. Material preparation, data collection and analysis were performed by Zhen Zhang and Yu Zhang. The first draft of the manuscript was written by Zhen Zhang and all authors commented on previous versions of the manuscript. All authors read and approved the final manuscript.

Funding This work was financially supported by National Key Research and development Project of "2020 Science and Technology to Boost Economy", National Agricultural Product Quality and Safety Risk Assessment Project (GJFP2020012) and 2019 Hainan Basic and Applied Basic Research Plan (Natural Science) High-level Talents Project (2019RC058).

Data Availability All data generated or analysed during this study are included in this published article [and its supplementary information files].

Code Availability Not applicable.

\section{Declarations}

Conflict of interest The authors declare that they have no conflict of interest.

Ethical Approval Not applicable.

Consent to Participate All authors worked on the final manuscript.

Consent for Publication All authors agreed to publish the final manuscript.

Open Access This article is licensed under a Creative Commons Attribution 4.0 International License, which permits use, sharing, adaptation, distribution and reproduction in any medium or format, as long as you give appropriate credit to the original author(s) and the source, provide a link to the Creative Commons licence, and indicate if changes were made. The images or other third party material in this article are included in the article's Creative Commons licence, unless indicated otherwise in a credit line to the material. If material is not included in the article's Creative Commons licence and your intended use is not permitted by statutory regulation or exceeds the permitted use, you will need to obtain permission directly from the copyright holder. To view a copy of this licence, visit http://creativecommons.org/licenses/by/4.0/. 


\section{References}

Adedipe NO, Hunt LA, Fletcher RA (1971) Effects of benzyladenine on photosynthesis, growth and senescence of the bean plant. Physiol Plant 25:151-153. https://doi.org/10.1111/journal.1399-3054. 1971.tb01105.x

Ahmed OM, Moneim AA, Yazid IA, Mahmoud AM (2010) Antihyperglycemic, antihyperlipidemic and antioxidant effects and the probable mechanisms of action of Ruta graveolens infusion and rutin in nicotinamide-streptozotocin-induced diabetic rats. Diabetologia Croat 39:15-35

Alscher RG, Donahue JL, Cramer CL (1997) Reactive oxygen species and antioxidants: relationships in green cells. Physiol Plantarum 100:224-233. https://doi.org/10.1111/journal.1399-3054. 1997.tb04778.x

Amin AA, Rashad M, Hassanein MS, Nabila MZ (2007) Response of some white maize hybrids to foliar spray with benzyladenine. Res J Agric Biol Sci 3:648-656

Ashley DA (1972) C-labelled photosynthate translocation and utilization in cotton plants. Crop Sci 12:69-74. https://doi.org/10. 2135/cropsci1972.0011183X001200010023x

Chang Y, Yang M, Chen S, Wang C (2016) Mulberry leaf polyphenol extract improves obesity by inducing adipocyte apoptosis and inhibiting preadipocyte differentiation and hepatic lipogenesis. J Funct Foods 21:249-262. https://doi.org/10.1016/journal.jff. 2015.11.033

Choi J, Kang HJ, Kim SZ, Kwon TO, Jeong SI, Jang SI (2013) Antioxidant effect of astragalin isolated from the leaves of Morus alba $\mathrm{L}$. against free radical-induced oxidative hemolysis of human red blood cells. Arch PharmRes 36:912-917. https:// doi.org/10.1007/s12272-013-0090-x

Diplock AT (1998) Defence against reactive oxygen species. Free Radical Res 29:463-467. https://doi.org/10.1080/1071576980 0300521

Dong B, Shao X, Lin H, Hu J (2017) Dissipation, residues and risk assessment of metaldehyde and niclosamide ethanolamine in pakchoi after field application. Food Chem 229:604-609. https:// doi.org/10.1016/journal.foodchem.2017.02.117

Elfving DC, Visser DB (2006) Timing cyclanilide and cytokinin applications in the nursery to obtain desired lateral branch height in apple and sweet cherry trees. J Am Soc Hortic Sci 41:1238-1242. https://doi.org/10.1007/s10658-006-9032-5

European Commission. Commission Regulation (EU) No 396/2005 of 23 February 2005 Amending Council Directive 91/414/EEC on maximum residue levels of pesticides in or on food and feed of plant and animal origin. 2005. http://ec.europa.eu/food/plant/ pesticides/eu-pesticides-database/public/?event=download. MRL. Accessed 15 Oct 2018

European Food Safety Authority (2020) Review of the existing maximum residue levels for 6-benzyladenine according to Article 12 of Regulation (EC) No 396/2005. EFSA J 18:6220-6247. https:// doi.org/10.2903/j.efsa.2020.6220

Fang S, Gao K, Hu W, Wang S, Chen B, Zhou Z (2019) Foliar and seed application of plant growth regulators affects cotton yield by altering leaf physiology and floral bud carbohydrate accumulation. Field Crop Res 231:105-114. https://doi.org/10.1016/j.fcr. 2018.11.012

Federal Legislative Registry of the Government of Australia (2017) Australia New Zealand Food Standards Code - Schedule 20 Maximum residue limits. Federal legislation Registry website. https://www.legislation.gov.au/Details/F2017C01208. Accessed 7 December 2017

Gao Z, Liang XG, Zhang L, Lin S, Zhao X, Zhou L, Shen S, Zhou SL (2017) Spraying exogenous 6-benzyladenine and brassinolide at tasseling increases maize yield by enhancing source and sink capacity. Field Crop Res 211:1-9. https://doi.org/10.1016/j.fcr. 2017.05.027

Gene G, Brummett DL (1993) Leaf age, decline in photosynthesis, and changes in abscisic acid, indole-3-acetic acid, and cytokinin in cotton leave. Field Crop Res 32:269-275

Gryn-Rynko A, Bazylak G, Olszewska D (2016) New potential phytotherapeutics obtained from white mulberry (Morus alba L.) leaves. Biomed Pharmacother 84:628-636. https://doi.org/10. 1016/j.biopha.2016.09.081

Gu X, Zhang G, Zhu X, Wang D, Zhu F, Ye G, Zhu D, Huang Z, Gu X, Wang C, Hu H (2010) Talking about the development and utilization of mulberry leaf tea. Shanghai Agricul Sci \& Tech 1:125-126. https://doi.org/10.3969/j.issn.1001-0106.2010.01. 088(-TranslatedinChinese)

Halim NIA, Phang IC (2017) Salicylic acid mitigates Pb stress in nicotiana tabacum. Herit Sci 1:16-19. https://doi.org/10.26480/gws. 01.2017.16.19

Hamidullah KR, Saini KS, Kumar A, Kumar S, Ramakrishna E, Maurya R, Konwar R, Chattopadhyay N (2015) Quercetin-6-C$\beta$-D-glucopyranoside, natural analogue of quercetin exhibits antiprostate cancer activity by inhibiting Akt-mTOR pathway via aryl hydrocarbon receptor. Biochimie 119:68-79. https://doi.org/10. 1016/journal.biochi.2015.10.012

Harborne JB, Williams CA (1992) Advances in flavonoid research since 1992. Phytochemistry 55:481-504. https://doi.org/10.1016/ s0031-9422(00)00235-1

Havsteen BH (2002) The biochemistry and medical significance of the flavonoids. Pharmacol Therapeut 96:67-202. https://doi.org/10. 1016/S0163-7258(02)00298-X

He H, Shi H (2014) Effects of 6-benzylaminopurine and alpha-naphthaleneacetic acid on growth and isoflavone contents of Pueraria phaseoloides hairy roots. Sheng Wu Gong Cheng Xue Bao 30:1573-1585. https://doi.org/10.13345/j.cjb.140001

He H, Qin J, Cheng X, Xu K, Teng L, Zhang D (2018) Effects of exogenous 6-BA and NAA on growth and contents of medicinal ingredient of Phellodendron chinense seedlings. Saudi J Bio Sci 25:1189-1195. https://doi.org/10.1016/j.sjbs.2017.11.037

He YD, Zhong XH, Jiang XF, Cong HQ, Sun HP, Qiao F (2020) Characterisation, expression and functional analysis of PAL gene family in Cephalotaxus hainanensis. Plant Physiol Bioch 156:461470. https://doi.org/10.1016/j.plaphy.2020.09.030

Hodaei M, Rahimmalek M, Arzani A, Talebi M (2018) The effect of water stress on phytochemical accumulation, bioactive compounds and expression of key genes involved in flavonoid biosynthesis in Chrysanthemum morifolium L. Ind Crops and Prod 120:295-304. https://doi.org/10.1016/j.indcrop.2018.04.073

Hu S (2020) Analysis on the development path of mulberry industry under the new development concept and its enlightenment. Newsletter of Sericul \& Tea 4:1-4

Huang H, Zhang X, Xu D, Zhou Y, Luo J, Lu M, Chen S, Wang L (2014) QuEChERs-high performance liquid chromatographytandem mass spectrometry for simultaneous determination of 21 plant growth regulator residues in fruits. Chin J Chromatogr 32:707-716. https://doi.org/10.3724/SP.J.1123.2014.03003

Hyunbok K, Jung DL, Aejung K, Yongsoon K, Kwon O (2017) Comparison with various mulberry leaves' and fruit's extract in lipid accumulation inhibitory effect at adipocyte model. The Kor Soci of Sericul Sci 35:1-6

Jadhav R, Puchchakayala G (2012) Hypoglycemic and antidiabetic activity of flavonoids: boswellic acid, ellagic acid, quercetin, rutin on streptozotocin-nicotinamide induced type 2 diabetic rats. Int $\mathrm{J}$ Pharm Pharm Sci 4:251-256

Jessica V, Brito AL, Pinheiro AL, Pinto D, Almeida J, Soares TL, Santana J (2019) Stimulation of 6-benzylaminopurine and metatopolin-induced in vitro shoot organogenesis and production of flavonoids of Amburana cearensis (Allemão) A.C. Smith). 
Biocatal Agric Biotechnol 22:1-9. https://doi.org/10.1016/j.bcab. 2019.101408

Jo SH, Ka EH, Lee HS, Apostolidis E, Kwon YI (2009) Comparison of antioxidant potential and rat intestinal a-glucosidases inhibitory activities of quercetin, rutin, and isoquercetin. J Nat Prod 2:52-60

Kappel VD, Cazarolli LH, Pereira DF, Postal BG, Zamoner A, Reginatto FH, Silva FRMB (2013) Involvement of GLUT-4 in the stimulatory effect of rutin on glucose uptake in rat soleus muscle. J Pharm Pharmacol 65:1179-1186. https://doi.org/10.1111/jphp. 12066

Kaur K, Gupta AK, Kaur N (2007) Effect of water deficit on carbohydrate status and enzymes of carbohydrate metabolism in seedlings of wheat cultivars. Indian J Biochem Bio 44:223-230. https://doi.org/10.1134/S1607672907040175

Kim AJ, Kim MH, Han MR, Choi MK, Kim MH, Kang NM (2008) Effects of mulberry-leaf powder tofu on carpus mineral density, biochemical markers of bone turnover and lipid profiles in female university students from choongnam consuming low calci $\mu$ m diet. The Kor J Food Nutri 21:71-78

Kim MJ, Kim HS, Kim AJ (2018) Optimization of mixing ratio of mulberry leaf, mulberry fruit, and silkworm for amelioration of metabolic syndrome. J Korean Medicine for Obesity Res 18:83-95. https://doi.org/10.15429/jkomor.2018.18.2.83

Li F, Zhang B, Chen G, Fu X (2017) The novel contributors of antidiabetic potential in mulberry polyphenols revealed by UHPLCHR-ESI-TOF-MS/MS. Food Res Int 100:873-884. https://doi. org/10.1016/j.foodres.2017.06.052

Li K, Hu G, Ma Y, Ye J, Wu J (2019) The present situation and countermeasures of mulberry tea industry in Nanchong under the background of belt and road initiative. Sichuan Sericul 47:7-9

Lichtenthaler HK (1987) Chlorophylls and carotenoids: pigment photosynthetic biomembranes. Method Enzymol 148:350-382. https://doi.org/10.1016/0076-6879(87)48036-1

Liu H, Qiu N, Ding H, Yao R (2008) Polyphenols contents and antioxidant capacity of 68 Chinese herbals suitable for medical or food uses. Food Res Int 41:363-370. https://doi.org/10.1016/j. foodres.2007.12.012

Liu Y, Wang QS, Ding YF, Liu ZH, Li GH, Wang SH (2009) Effect of nitrogen and 6-BA on development of tillering bud and its physiological mechanism. Acta Agronomica 35:1893-1899. https://doi.org/10.3724/SP.J.1006.2009.01893

Liu X, Xu D, Yang Z, Zhang N, Pan L (2018) Investigation of exogenous benzyladenine on growth, biochemical composition, photosynthesis and antioxidant activity of Indian sandalwood (Santalum album L.) seedlings. J Plant Growth Regul 37:11481158. https://doi.org/10.1007/s00344-018-9806-y

Liu QZ, Xi B, Sun YL, Xu WR, Dai HJ (2019) Effects of exogenous 6-BA on anthocyanin content and expression of related genes in grape berry. Nat Sci Ed 47:112-125. https://doi.org/10.13207/j. cnki.jnwafu.2019.02.014

Ma Q, Zhang T, Zhang P, Wang ZY (2016) Melatonin attenuates postharvest physiological deterioration of cassava storage roots. J Pineal Res 60:424-434. https://doi.org/10.1111/jpi.12325

Ma Q, Santhanam RK, Xue Z, Guo Q, Gao X, Chen H (2018) Effect of different drying methods on the physicochemical properties and antioxidant activities of mulberry leaves polysaccharides. Int J Biol Macromol 119:1137-1143. https://doi.org/10.1016/j. ijbiomac.2018.08.023

Mandal SM, Chakraborty D, Dey S (2010) Phenolic acids act as signaling molecules in plant-microbe symbioses. Plant Sifnal Behav 5:359-368. https://doi.org/10.4161/psb.5.4.10871

Marı'n FR, R1'o JAD, (2001) Selection of hybrids and edible citrus species with a high content in the diosmin functional compound. Modulating effect of plant growth regulators on contents. J Agric Food Chem 49:3356-3362. https://doi.org/10.1021/jf010 $052 \mathrm{n}$
Melkozernov AN, Blankenship RE (2006) Photosynthetic functions of chlorophylls. Photosynth Res 25:397-412. https://doi.org/10. 1007/1-4020-4516-6_28

Miao H, Zeng W, Zhao M, Wang J, Wang Q (2020) Effect of melatonin treatment on visual quality and health-promoting properties of broccoli florets under room temperature. Food Chem 319:1-9. https://doi.org/10.1016/j.foodchem.2020.126498

Mittler R (2002) Oxidative stress, antioxidants and stress tolerance. Trends Plant Sci 7:405-410. https://doi.org/10.1016/S13601385(02)02312-9

Mittler R (2017) ROS are good. Trends Plant Sci 22:11-19. https://doi. org/10.1016/j.tplants.2016.08.002

Monika P, Ewa F (2016) Antioxidant properties of paratha type flat bread enriched with white mulberry leaf extract. Indian J Tradit Know 15:237-244

Ngapui R, Gogoi P, Chowlu K, Rao AN (2014) Effects of NPK and 6-benzylaminopurine on growth and flowering of two orchid Genera. Ls Inter J Life Sci 3:85. https://doi.org/10.5958/2319-1198. 2014.01090.2

Ni J, Gao C, Chen M, Pan B, Ye K, Xu Z (2015) Gibberellin promotes shoot branching in the perennial woody plant Jatropha curcas. Plant Cell Physiol 56:1655-1666. https://doi.org/10.1093/pcp/ pcr089

Pan S, Rasul F, Li W, Tian H, Mo Z, Duan M, Tang X (2013) Roles of plant growth regulators on yield, grain qualities and antioxidant enzyme activities in super hybrid rice (Oryza sativa L.). Rice 6:1-9

Ranjan B, Kumar R, Verma N, Mittal S, Pakrasi PL, Kumar RV (2017) Evaluation of the Antidiabetic Properties of S-1708 Mulberry Variety. Pharmacogn Mag 13:S280-S288. https://doi.org/10. 1186/1939-8433-6-9

Salerno M, Maltese A, Gabrieletripi Romano P, Parisi L (2017) Separaxion anxiety in pediatric migraine without aura: a pilot study. Acta Medica Mediterr 33:621-625. https://doi.org/10.19193/ 0393-6384_2017_4_092

Schmittgen TD (2008) Analyzing real-time pcr data by the comparative ct method. Nat Protoc 3:1101-1108. https://doi.org/10.1038/ nprot. 2008.73

Sheng Y, Zheng S, Zhang C, Zhao C, He X (2018) Mulberry leaf tea alleviates diabetic nephropathy by inhibiting PKC signaling and modulating intestinal flora. J Funct Foods 46:118-127

Shih CH, Chu H, Tang LK, Sakamoto W, Maekawa M, Chu IK, Lo WC (2008) Functional characterization of key structural genes in rice flavonoid biosynthesis. Planta Med 228:1043-1054. https://doi. org/10.1007/s00425-008-0806-1

Sprent JI (1967) The effects of benzyladenine on the growth and development of peas. Planta 78:17-24

Testai L (2015) Flavonoids and mitochondrial pharmacology: a new paradigm for cardioprotection. Life Sci 135:68-76

Thabti I, Elfalleh W, Tlili N, Ziadi M, Campos MG, FerchichiPhenols A (2013) Flavonoids, and antioxidant and antibacterial activity of leaves and stem bark of Morus species. Int J Food Prop 17:842854. https://doi.org/10.1080/10942912.2012.660722

Wang LF (2014) Physiological and molecular responses to drought stress in rubber tree (Hevea brasiliensis Muell. Arg.). Plant Physiol Bioch 83:243-249. https://doi.org/10.1016/j.plaphy.2014.08. 012

Wang L, Luo Z, Ban Z, Jiang N, Yang M, Li L (2020) Role of exogenous melatonin involved in phenolic metabolism of Zizyphus jujuba fruit. Food Chem 341:1-9. https://doi.org/10.1016/j.foodc hem.2020.128268

Xia XJ, Huang LF, Zhou YH, Miao WH, Kai S, Wu JX, Asami T, Chen Z, Yu JQ (2009) Brassinosteroids promote photosynthesis and growth by enhancing activation of Rubisco and expression of photosynthetic genes in Cucumis sativus. Planta 230:1185-1196. https://doi.org/10.1007/s00425-009-1016-1 
Xie W, Chen C, Jiang Z, Wang J, Zhang X (2015) Apocynum venetum attenuates acetaminophen-induced liver injury in mice. Am J Chinese Med 43:457-476. https://doi.org/10.1142/S0192415X1 5500299

Xu F, Yang Z, Chen X, Jin P, Wang X, Zheng Y (2012) 6-Benzylaminopurine delays senescence and enhances health-promoting compounds of harvested broccoli. J Agric Food Chem 60:234-240. https://doi.org/10.1021/jf2040884

Yang X, Yang L, Zheng H (2010) Hypolipidemic and antioxidant effects of mulberry (Morus alba L.) fruit in hyperlipidaemia rats. Food Chem Toxicol 48:2374-2379. https://doi.org/10.1016/j.fct. 2010.05.074

Yang G, Yu L, Zhang K, Zhao Y, Guo Y, Gao C (2017) A ThDREB gene from Tamarix hispida improved the salt and drought tolerance of transgenic tobacco and T.hispida. Plant Physiol Bioch 113:187-197. https://doi.org/10.1016/j.plaphy.2017.02.007

Yu Y, Huang J, Shi X, Deng Z (2018) Research progress of mulberry leaf food development in China. J Food Saf Food Qual 9:1572-1578

Zhang D, Wan Y, Hao J, Hu R, Chen C, Yao X, Zhao W, Liu Z, Li L (2018a) Evaluation of the alkaloid, polyphenols, and antioxidant contents of various mulberry cultivars from different planting areas in eastern China. Ind Crop Prod 122:298-307. https://doi. org/10.1016/j.indcrop.2018.05.065

Zhang L, Shen C, Wei J, Han W (2018b) Effects of exogenous 6-benzyladenine on dwarfing, shoot branching, and yield of tea plant (Camellia sinensis). HortScience 53:651-655
Zhang Y, Huber DJ, Hu M, Jiang G, Gao Z, Xu X, Jiang Y, Zhang Z (2018c) Delay of postharvest browning in litchi fruit by melatonin via the enhancing of antioxidative processes and oxidation repair. J Agric Food Chem 66:7475-7484

Zhao S, Park CH, Li X, Kim YB, Park SU (2015) Accumulation of rutin and betulinic acid and expression of phenylpropanoid and triterpenoid biosynthetic genes in mulberry (Morus alba L.). J Agric Food Chem 63:8622-8630. https://doi.org/10.1021/acs. jafc. 5 b03221

Zheng H, Liu W, Liu S, Liu C, Zheng L (2019) Effects of melatonin treatment on the enzymatic browning and nutritional quality of fresh-cut pear fruit. Food Chem 299:1-8

Zhou C (2015) Preliminary study on trial production and development technology of mulberry leaf tea. Newsletter Sericul Sci 37:29-31. https://doi.org/10.3969/j.issn.1006-0561.2017.02.009(-Translated inChinese)

Publisher's Note Springer Nature remains neutral with regard to jurisdictional claims in published maps and institutional affiliations. 